Гордана Р. ШТРБАЦ*

Универзитет у Новом Саду

Филозофски факултет
Оригинални научни рад

Примљен: 18. 09. 2017.

Прихваћен: 27. 12. 2017.

\title{
УЛОГА РЕЧНИКА У КОГНИТИВНОЛИНГВИСТИЧКИМ ИСТРАЖИВАњИМА СРПСКОГ ЈЕЗИКА
}

\begin{abstract}
Централно место у когнитивнолингвистичким истраживањама заузима концепт, којем се приступа као менталној јединици с уређеном унутрашњом структуром, у односу на коју се језик поставља као њена вербализована манифестација. Због тога је опис језичких јединица један од начина да се приступи концепту и утврди његова структура. Главни циљ овог рада, који се ослања управо на овакво теоријско полазиште, јесте да се укаже на улогу и значај речника у лингвоконцептолошким истраживањима, што се чини на примеру концепта памет.
\end{abstract}

Кључне речи: когнитивна лингвистика, концепт памет, речници.

\section{1. Уводне напомене}

1.1. Последњих тридесетак година когнитивна лингвистика постаје доминантан правац у оквиру лингвистичких истраживања и когнитивистике уопште, а развија се као резултат изучавања сложених односа између језика и мишљења. Предмет когнитивне лингвистике јесте језик као репрезентација мисаоних делатности које се активирају при спознаји стварности. Ова дисциплина развија се на психолингвистичким постулатима о људском мишљењу као невербалном процесу, оствареном помоћу концепата, који представљају основне јединице мишљења и чине базу универзалног предметног кода. Семантичко-когнитивни приступ унутар когнитивне лингвистике, а пре свега његово лингвоконцептолошко усмерење, бави се саставом и семантиком језичких јединица које вербализују одређени концепт с циљем да се опише његов садржај и одреди његово место у концептосфери (Попова/Стерњин 2007: 18-22).

\footnotetext{
*strbacsn@eunet.rs

${ }^{* *}$ Истраживање је рађено у оквиру пројекта Стандардни српски језик: синтаксичка, семантичка и прагматичка истраживаға (бр. 178004), који финансира Министарство просвете, науке и технолошког развоја Републике Србије.
} 
1.2. У одређењу 3. Попове и Ј. Стерњина (2007: 34), концепт је дискретна ментална творевина с уређеном унутрашњом структуром која је резултат когнитивне активности личности и заједнице, а носилац је енциклопедијске информације о одређеном предмету или појави, као и податка о односу говорника према њима. Концепти могу имати свој језички израз, тј. могу бити исказани различитим језичким јединицама, али у исто време многи од њих не морају бити вербализовани, што зависи од степена њихове комуникативне релевантности. Именовање концепта, тј. постојање посебне речи за његово исказивање није обавезан услов за издвајање концепта као реално постојеће менталне јединице (Попова/Стерњин 2007: 78). О његовом значају сведочи не само број језичких јединица које га номинују већ и њихова учесталост у говорној заједници.

Структурирају га три основне компоненте: сликовна, информациони садржај и интерпретативно поље. Сликовна компонента састоји се од перцептивних когнитивних обележја, формираних помоћу чула, и метафоричних обележја. Информациони садржај укључује минимална али суштинска обележја, неопходна за одређивање концепта. Интерпретативно поље садржи обележја која су резултат интерпретације информационог садржаја - тичу се вредносне, емоционалне и друге оцене предмета или појма, искуства с њима, прагматичког односа, тј. њихове примене итд. (Попова/Стерњин 2007: 104-115).

1.3. Узимајући у обзир методе, задатке и циљеве когнитивнолингвистичког правца, у овом раду настоји се указати на улогу речника српског језика у овој врсти лингвистичких истраживања. На примеру концепта памет покушава се истаћи значај различитих типова лексикографских остварења као: 1. извора корпусног материјала помоћу којег се дати концепт вербализује, 2. извора семантичких и других података примењених у поступку когнитивне интерпретације и моделовања садржаја и структуре концепта. Стога ће у даљем излагању бити описано место и значај речника у методологији когнитивнолингвистичких истраживања. У теоријско-методолошком приступу концепту у највећој мери овај рад ослања се на поставке 3. Попове и J. Стерњина (2007).

\section{2. Методологија когнитивнолингвистичких истраживања и улога речника у њима}

2.1. У истраживању концепата примењује се методолошки поступак који обухвата неколико етапа: 1. формирање номинационог поља концепта, 2. опис семантике језичких средстава која га сачињавају, 3. когнитивну интерпретацију семантичког описа, 4. моделовање концепта (Попова/Стерњин 2007: 186-217). У овим етапама постојећи речници српског језика учествују на различите начине. На примеру концепта памет биће показано како се релевантни подаци из одређених типова речника могу искористити у функцији његовог описа и моделовања. 
2.2. Прва етапа своди се на сачињавање номинационог поља концепта, под којим се подразумева укупност језичких средстава којима се вербализује. Чине га различите језичке јединице као што су: лексеме које непосредно именују концепт, затим њихови синоними, антоними, деривати, фразеологизми, паремиолошки фонд језика, поређења, асоцијације, примери забележени у књижевноуметничким, публицистичким и другим текстовима итд. Лексеми која именује сам концепт (памет), као и придеву изведеном од ње (паметан), може се приписати статус кључних речи, будући да су оне довољно опште по својој семантици и стилски неутралне. Пошто се у овом истраживању испитује улога речника у лингвоконцептолошким истраживањима, из лексикографских извора могу се издвојити следећи низови лексичких јединица груписаних у својеврсна потпоља номинационог поља концепта памет:

а. лексички, састављен од кључних речи - nамет, паметан; њихових синонима ${ }^{1}$ - интелигенција, мудрост, разум, ум, разборитост, оштроумност, мудар, разуман, уман, разборит, проницљив итд.; антонима - глуп, ограничен итд.; и жаргонизама - минте, вијуга, вијуге, кефало, кликер итд.; ${ }^{2}$

б. деривациони, изведен од кључних речи (памет и паметан) - паметник, паметница, паметььковић, непаметан, препаметан, паметовати, памтити, памтилац, запамтити, злопамтити, злопамтило итд.;

в. фразеолошки с кључном речју памет као саставницом односно с лексиком другачијег састава у чије је значење уткан податак о менталној способности - бити кокошје (пачје, пилеће, кратке, ретке, плитке) памети, бери памет, бити лаке памети, бити коме на памети (у памети), бити при (здравој) памети, имати бистру (добру) главу, имати мозга (у глави), глуп као ћускија итд.;

г. асоцијативни, с кључном речју паметан као стимулусом - глуп 94; човек 53; интелигентан 52; ја 30; мудар 22 итд.

Овако богато номинационо поље могуће је сачинити захваљујући постојању одговарајућих речника у српском лексикографском корпусу. Побројане лексичке јединице ексцерпиране су из неколико различитих извора: лексеме синонимне кључним речима преузете су из лексикографског дела М. Лалевића - Sinonimi i srodne reči srpskohrvatskoga jezika; жаргонизми су ексцерпирани из Речника жаргона Д. Андрића, а деривати из друге свеске $\mathrm{Ce}$ мантичко-деривачионог речника; фразеолошки корпус формиран је на основу фразеолошког речника Ј. Матешића и Речника српскохрватскога књижевног језика Матице српске (РМС), док је асоцијативно поље представљено на основу Асоцијативног речника српскога језика.

2.3. Из већине наведених извора преузети су и семантички описи пописаних лексичких, фразеолошких и других јединица, који су се показали

\footnotetext{
${ }^{1}$ Јасно је да се међу лексемама из групе синонима не остварује потпуна семантичка једнакост, ни међусобна ни у односу према кључним речима, мада се разлике међу њима не могу јасно уочити само на основу лексикографских дефиниција. Због ограниченог простора о овоме се неће детаљније расправљати, будући да то може бити предмет једног посебног истраживања.

2 Због ограниченог простора не наводе се све јединице које улазе у номинационо поље. Оне ће бити видљиве у даљој анализи.
} 
као одговарајући у поступку издвајања сема важних за даљу когнитивну интерпретацију као форму вишег, апстрактног облика уопштавања значења. Наиме, на основу лексикографских дефиниција предочених у одговарајућим речницима, а пре свега у РМС и фразеолошком речнику, могуће је издвојити најважније семе за чланове побројаних потпоља.

У лексичком систему номинационог поља, који чине кључне речи и њихови синоними и антоними, истакнутим се могу сматрати следеће семе: способност мишљења, схватања, расуђивања, способност логичног, брзог и правилног разумевања, способност улажења у суштину проблема и његовог решавања, способност предвиђања, способност трезвеног и прибраног поступања, својство као резултат стицања знања, способност објективног мишљења, те одсуство ових способности.

Лексикографске дефиниције деривационе парадигме лексеме nамет у Семантичко-деривационом речнику преузете су из РМС, тако да се и у семантичком опису деривата релевантним извором може сматрати управо овај једнојезични речник. На основу тумачења предочених у њему, уочена су следећа семантичка обележја: способност човека да мисли, схвата, просуђује, спознаје (одсуство такве способности), склоност ка истицању ових особина, при чему их носилац реално не поседује тако да се исказује подругљив однос говорника према денотату, процес задржавања података у свести, својство да се нешто може сачувати у свести.

У фразеолошком корпусу номинационог поља датог концепта на основу дефиниција утврђених у фразеолошком речнику и Матичином шестотомнику издвојене су следеће компоненте значења: способност тачног, правилног и логичног просуђивања / одсуство такве способности, способност нормалног расуђивања / одсуство такве способности, присуство искуства, знања / одсуство искуства, знања, занесеност, лакомисленост, површност, збуњеност, смушеност, способност чувања података у свести / одсуство такве способности, својеглавост/поводљивост, опседнутост каквом мишљу, идејом.

И семантички описи лексичких јединица које улазе у асоцијативно поље датог концепта изведени су из лексикографских дефиниција наведених у РМС. Као доминантна могу се издвојити следећа семантичка обележја: способност логичног, брзог и правилног разумевања, способност улажења у суштину проблема и његовог решавања / одсуство таквих способности, способност овладавања новим знањима, успех као последица поседовања датог својства.

2.4. Когнитивна интерпретација сема подразумева издвајање диференцијалних и класификационих когнитивних обележја, која су значајна за структурирање концепта. ${ }^{3}$ То је вид уопштавања сема спроведен тако што се блиске компоненте међусобно удружују и подводе под заједничко когнитив-

${ }^{3}$ Под диференцијалним когнитивним обележјем подразумева се посебно обележје предмета које се одражава у структури концепта као елеменат његовог садржаја. Класификациона обележја су, такође, компоненте садржаја концепта које одражавају параметре категоризације и она су увек заједничка за једну групу концепата (Попова/Стерњин 2007: 128). 
но обележје. За сваки сегмент номинационог поља биће сачињен хијерархијски списак ових обележја.

2.4.1. Кључне речи и њихови синоними обједињени су заједничким когнитивним обележјем 'способност мишљења, схватања, просуђивања, спознаје'. Оно је у најпотпунијем облику репрезентовано лексемама памет, ум, умље, умност, разум, разумност, мисаоност/мисленост, мозак, глава, паметан, разуман, уман, мисаон, смисаон, дотупаван (15). Ова основна особина испољава се на различите начине - а. као повишени степен моћи расуђивања, процењивања и изналажења решења: интелигенција, мудрост, мудрина, разборитост, оштроумност/оштроумље, расудност, пронииљивост, интелигентан, мудар, разборит, очтроуман, расудан, пронииљив, разложан/разложит, бистар (15); б. као способност дубоког задирања у проблем: дубокоумност, дубокомисаоност, дубокомисленост, темељност/ темељитост, дубина, дубокоуман, дубокомисаон, дубокосмислен, темељан/ темељит (9); в. као прибраност у размишљању: сабраност, прибраност, трезвеност, сабран, разабран, прибран, трезвен (7); г. као способност предвиђања: далековидост, видовитост, далековидан/далековид, видовит (4); д. као опрезност у процењивању: промишьеност, промишьен, смотрен, увиђаван (4); ђ. као резултат усвајања знања: ученост, учен, свезнао (3); е. као интелектуална способност непримерена годинама њеног носиоца: стармали (1); ж. као способност објективног расуђивања: свестан (1). Њима супротне вредности обележене су јединицама: глуп, ограничен, површан и сл.

2.4.2. Уопштавањем сема из семантичког описа деривата који припадају номинационом пољу концепта памет успостављају се следећа когнитивна обележја, од којих се нека јављају у својим позитивним и негативним ликовима:

1. 'способност мишљења, схватања, просуђивања, спознаје' (3) - naмет, препамет, памеиа;

2. ' 'ментални процес' $(16+3=19)^{4}$

a. стицање / губљење наведене способности - опаметити, оnaмећивати, пропаметити се / испаметити се, распаметити се;

б. $\quad$ чување / нечување података у свести - паметовати, паметовање, 5 памтити, памћење, запамтити, запамћење, запамћивати, запамћивање, попамтити, припамтити, упамтити, злопамтити, злопамћење / непамћење;

3. 'интелектуално својство' $(8+6=14)$

a. које се тиче (не)способности мишљења, схватања, просуђивања, спознаје (изражено у одређеном степену) - паметан,

${ }^{4}$ Први број у загради представља број лексема позитивног значења, други број указује на скуп јединица с негативним значењем, а последњи у низу обележава укупан број јединица којима се исказује дато когнитивно обележје.

${ }^{5}$ Ова и претходна лексема се на основу примарног значења подводе под дато обележје, док у секундарним значењима указују на своју супротност, с обзиром на компоненту ироније укључену у њихов семантички садржај. 
препаметан, паметно, препаметно / непаметан, непаметно, беспаметан, беспаметно, распамећен, распамећеност;

б. које се тиче способности чувања података - памтљив, памтљивост, злопамтив (злопамтљив), злопамтило;

4. 'особа' $(7+3=10)$

a. која поседује / не поседује способност мишљења, схватања, просуђивања, спознаје - паметник (паметьак), паметниц̧а / паметьаковић, паметовалаи, беспамет;

б. $\quad$ која поседује / не поседује способност чувања података - naметар, памтилаи, памтило, памтилица / непамтило;

5. 'својство појма који подлеже чувању / одсуство тог својства' $(3+3$ =6) - запамтљив, упамтљив, паметодостојан / незапамћен, незапамћено, непамћен;

6. 'временска квантификација' (1) - памтивек;

7. ' 'начин спровођења неке активности који је последица способности памћења' (1) - напамет.

2.4.3. У оквиру фразеолошког поља, на основу семантичких описа понуђених у фразеолошком и дескриптивном речнику, може се установити систем од низа когнитивних обележја распоређених често у опозитним релацијама:

1. 'својство' (а. $10+32=42 ; 6.5+22=27$; в. $6+6=12$ )

a. које се тиче способности тачног, логичног просуђивања и правилног оцењивања ситуације, проблема итд. (бити паметан, мудар, интелигентан / бити умно ограничен, неинтелигентан) - имати бистру (добру) главу, имати мозга (у глави), бити кокошје (пачје, пилеће, плитке, кратке, ретке) памети, врана је коме памет испила (попила) итд.;

б. које се тиче способности нормалног расуђивања (бити здравог разума / бити луд, малоуман) - бити при (здравој) naмети, не бити при (својој, здравој, чистој) памети, јести (најести се) бунике, имати цицввару у глави, ударен мокром чарапом итд.;

в. које се тиче степена усвојеног знања и искуства (бити образован, искусан / бити неук, незналица, незрео, неискусан, лакомислен, површан) - не бити од јуче, није се ко јуче родио, стари зеи, човек од књиге, живи лексикон, књишки мољач / не знати ни бе, празна (щупља) глава, дечја памет, бити лаке (женске) памети, женска памет;

г. које се тиче (не)самосталности у размишљању и деловању (бити својеглав / поводљив) - ићи за својом памети / ићи за туђом памети;

2. 'ментални процес' (а. $14+18=32 ;$ б. $14+6=20$ )

a. који се тиче могућности нормалног, разумног расуђивања (опаметити [се], уразумити [ce], добро размислити / [по]лудети, 
бити сметен, збуњен, занесен, залудити кога) - дозвати се (к) памети, научити кога памети, губити (изгубити) памет, сићи (скренути, заћи) с памети итд.;

б. који се тиче задржавања података у свести (бити у мислима, сећању, сетити се [сећати се], упамтити, подсетити кога на шта / не помишљати на шта, не сећати се, не мислити на шта, заборавити, бити заборављен) - бити коме на памети (у памети), пребирати шта по памети (у памети), избацити (избрисати, испустити) шта из памети, сметнути (свргнути) шта с памети итд.;

в. који се тиче других врста умног ангажовања (умног напрезања, маштања) (2) - оштрити (изочтрити) памет, преноси кога памет;

3. 'емоционални процес' (2)

a. беснети - излазити из памети;

б. $\quad$ бити избезумљен - стаје коме памет;

4. 'вербалне активности' (3)

а. мудровати, правити се паметан - просипати памет;

б. (непотребно) поучавати кога, наметати, наметнути коме своје мишљење - (о)солити коме памет, учити кога памети;

5. ' 'активности' (1) - имати више среће него памети;

6. 'временска квантификација' (1) - што је памети љуудкее.

2.4.4. Будући да лексикографска дефиниција, због природе лексикографског посла, не одражава у потпуности оно што је у свести носилаца језика поводом неке реалије или појма, она мора бити допуњена подацима добијеним на основу психолингвистичких експеримената. ${ }^{6}$ На основу асоцијата добијених из асоцијативног поља придева паметан стиче се увид у читав низ когнитивних обележја помоћу којих се дати концепт идентификује. ${ }^{7}$ Реч је, дакле, о способности мишљења схватања, просуђивања, спознаје: интелигениија, ум, интелект, интелигент, интелигентност, мисао, мудрост, памет, резон (28). То је уједно и својство које се остварује као могућност или немогућност тачног, логичног просуђивања и правилног оцењивања ситуације, те решавања проблема итд.: интелигентан, мудар, мозак, бистар, глава, уман, геније, IQ, оштроуман итд. (168). Одлика је, пре свега, човека: човек, ja, дечко, дечак, мушкараи, друг, јесам, младић, сам, тата, Биља, Боћа, брат, дете итд. (127), и то људи одређеног старосног доба: млад, стар (2), али се приписује и неким животињама: пас, слон, голуб, к'о пчелица, пчела, пчелица, коњ, магараи, мрав (20), као и предметима: телевизор (1). Најчешће се везује за процесе учења и бављење науком: студент, ученик, Ђак, Ајнштајн, штребер,

${ }^{6}$ J. Бартмињски уводи термин когнитивна дефиниција, која је усмерена ка утврђивању сазнајних садржаја фиксираних у језику и начину структурирања тих садржаја путем језика (Бартмињски 2011: 97).

${ }^{7}$ Асоцијативна поља самостално могу бити богат извор података у лингвоконцептуалним истраживањима, што показује, на пример, опис језичке слике породице у српском и руском језику (в. Стефановић 2012: 22-46). 
књига, научник, учен, начитан, образован, професор, школа, Тесла итд. (120). Иде у пару с другим особинама личности као што су изглед: леп, наочари, ћелав, и леп, лепота, наочаре, неко с наочарима (12), карактерним и другим својствима: добар, уображен, вредан, брилијантан, бриљантан, ћутљив, доброћудан, досадан, дрчан, иронија, лукав итд. (37). Дато својство покреће на одређено деловање: избор, потез, одговор, ииль, ефикасан, избори, план, предлог, превара, пад, програм, разговор, живот (23). Изазива најчешће позитивне реакције у окружењу: дивљење, благо њему, иењен, неприхваћен, популаран, прецењен, страва, супер, свака част, треба бити, важно, утисак, срећан, има среће, срећа, благослов (19), а његови носиоци уживају одређен статус и воде успешнији живот: ауторитет, имућан, испред, моћ, надмоћан, најбогатији, напредак, успешан, успех (11). Испољавају га стварне и фиктивне личности из појединих струка или области: Шешељ, Ђелић, Изи, Корошец, Коста Чавошки, Кочтуница, Лабус, пчелица Маја, полицајац, политичар, уметник (12). Ово својство није честа појава: реткост, ретко, ретко ко, само један (6). Стиче се рођењем: природно (1), и може се испољити у извесном ступњу: много, највише, релативан (3).

2.5. Моделовање концепта спроводи се најчешће у три етапе: 1. формирање његове макроструктуре, 2. утврђивање хијерархије когнитивних обележја и 3. на основу тога утврђивање структуре концепта с обзиром на његову организацију по пољима. Због ограниченог простора, као и због чињенице да се неки подаци понављају, наведене етапе неће бити спроведене за сваки тип номинационог поља појединачно, него за номинационо поље у целини, при чему ће друга и трећа етапа бити обједињене.

Прва компонента макроструктуре концепта јесте сликовна и њу чине когнитивна обележја којима се на концепт упућује на нивоу визуелне представе. То су углавном асоцијати којима се указује на познате личности из различитих области: Њутн, Никола Тесла, пчелица Маја и сл. Његов информациони садржај образују елементи који описују суштинску природу датог концепта одређујући га као (не)способност правилног расуђивања (nамет, интелигенција и сл.) односно као својство особе која је (не)способна да логично расуђује и решава пред собом постављене проблеме (паметан, мудар, интелигентан, имати мозга у глави, бистар као боза итд.). Његову информациону базу, такође, чине и интелектуални процеси који су непосредно условљени датом особином, као што су памћење (памтити, упамтити, записати у памет, избрисати шта из памети и сл.), нормалног расуђивања (срести се с памећу, узети памет у главу и сл.), те усвајање знања (књига, учен, професор, школа итд.). Интерпретативни садржај своди се на она обележја концепта која откривају емоционални и други однос говорника према стварности. Она се, у првом реду, могу ишчитати на основу експресивне вредности јединица фразеолошког поља концепта, која показује позитиван, афирмативан однос према датом својству и особама које су њени носиоци. Дакле, по правилу позитивно су конотирани фразеологизми са значењем 'бити паметан, мудар', нпр. имати мозга у глави, имати бистру главу, док су негативно обојени њима антонимични изрази, са значењем 'бити глуп' 
- бити кокошје памети, глуп као ћускија. С друге стране, ту су и асоцијати који показују да се посматрана интелектуална особина позитивно вреднује јер изазива позитивне реакције у окружењу (благо њему, цењен, популаран, свака част, има среће, благослов), а њени носиоци уживају углед и имају успешан живот (ауторитет, надмоћан, напредак).

На основу хијерархије когнитивних обележја, тј. учесталости њиховог јављања у номинационом пољу формираном на основу лексикографског корпуса, предочене у претходном одељку, може се установити организација поља посматраног концепта. Његово језгро или центар чине когнитивна обележја на основу којих се посматрани концепт одређује као способност мишљења, схватања, просуђивања, спознаје (памет, ум, разум и сл.), затим као својство које се испољава кроз дату способност (интелигентан, паметница, глуп, имати мозга у глави) односно као својство које се испољава кроз способност нормалног расуђивања (бити при здравој памети, имати ициввару у глави). Под овим обележјима обједињен је највећи број номинационих јединица - има их око 300. У знатно мањем обиму (135) заступљене су јединице које указују на аспекат усвајања знања и искуства, тј. на могућност учења: стари зеи, живи лексикон, ученик, књига, икола, искуство, образовање, математика итд. Ближој периферији припадају обележја која осветљавају наведени концепт као особину људи: човек, дечак, друг, младић и сл. У њој је 127 именовања. У истом пољу, са 71 јединицом, налазе се својства која маркирају менталне процесе као посебан сегмент концепта, при чему се првенствено има у виду могућност или немогућност разумног расуђивања, као и памћења: упамтити, запамтити, памтило, утерати коме памет у главу, завртети коме памет, бити коме на памети, пребирати по памети итд. Даљу периферију чине обележја која указују на то да се уз дато интелектуално својство јављају пратеће црте личности: добар, уображен, вредан, бриљантан, ћутљив, доброћудан, досадан, дрчан (37), као и она која показују да наведена особина мотивише и одређену врсту деловања: избор, потез, одговор, план, предлог (23). Крајња периферија осветљава ништа мање значајне сегменте концепта, као што су његово везивање за поједине животиње, однос окружења према људима који поседују дато својство, њихов изглед, статус и сл.

\section{3. Завршна разматрања}

Истраживање мањег обима спроведено у овом раду показује вишеструк допринос речника у лингвоконцептолошким истраживањима. Они, у првом реду, служе као извори јединица за формирање номинационог поља концепта. Што је лексикографска пракса богатија у типолошком погледу, то су могућности за састављање номинационог поља веће и прецизније, а посао њиховог прикупљања знатно олакшан. С тим у вези може се истаћи као веома значајно постојање у нашем лексикографском корпусу посебних речника какви су: речник синонима, затим семантичко-деривациони речник, 
на основу којег је било једноставно сачинити деривациону парадигму посматраног концепта, потом фразеолошки и асоцијативни речник. Наравно, добар дескриптивни једнојезични речник, какав је РМС или РСАНУ, може и сам понудити адекватну грађу с обзиром на чињеницу да су у њему садржани сви побројани типови лексичких јединица, осим асоцијација. Уз то, у дескриптивни речник, какав је, на пример, РСАНУ, укључене су и паремиолошке форме, које, међутим, у овом истраживању нису узете у обзир због органиченог простора, али и недостатка паремиолошких речника на основу којих би се могао успоставити исцрпан списак ових јединица и описати околносни оквир њихове употребе. ${ }^{8}$

PMC се показао као веома погодан извор семантичког тумачења одговарајућих лексичких јединица, на основу којих је извршена когнитивна интерпретација. Ова фаза у опису концепта свакако је у знатној мери допуњена подацима из асоцијативног речника. Наиме, иако лексикографске дефиниције дају прецизне семантичке описе, оне се често показују као недовољне у лингвоконцептолошким истраживањима будући да сваки говорник има нека своја индивидуална искуства и знања везана за одређене појаве и предмете у стварности. Стога је психолингвистичко значење лексичких јединица, тј. оно које открива схватања и сазнања појединачних говорних представника незаобилазно у истраживањима ове врсте. У том смислу речници асоцијација представљају важну ризницу оваквих података.

И на крају ваља истаћи празнине у нашој лексикографији које ће се у даљој будућности надоместити. Оне се првенствено тичу израде фреквенцијских речника, и то не само речника појединих писаца већ и оних општијег типа, којима би био обухваћен знатно шири корпус. Уз то, когнитивнолингвистичка истраживања била би знатно олакшана уколико би постојали и неки веома уско спецификовани речници, какав је, на пример, речник метафора.

\section{Извори}

PMC: Речник српскохрватскога књижевног језика, I-III. Нови Сад - Загреб: Матица српска - Матица хрватска, 1967-1969; IV-VI, Нови Сад: Матица српска, 1971-1976.

PСАНУ: Речник српскохрватског књижевног и народног језика, I-. Београд: САНУ, Институт за српски језик САНУ, 1959-.

СДР: Д. Гортан-Премк, В. Васић, Љ. Недељков (ур.), Семантичко-дериваииони речник. Свеска 1: Човек - делови тела, Нови Сад: Филозофски факултет, 2003.

\footnotetext{
8 Значајан удео у оваквим истраживањима може имати тематска класификација пословица спроведена по лексичком принципу (в. Јовановић 2006).
} 


\section{ЛИТЕРАТУРА}

Андрић 2005: Д. Андрић, Речник жаргона, Београд: Zepter Book World.

Бартмињски 2011: Ј. Бартмињски, Језик - слика - свет. Етнолингвистичке студије, Београд: SlovoSlavia.

Јовановић 2006: Ј. Јовановић, Књига српских народних пословица I, II, Београд: Научно друштво за неговање и проучавање српског језика.

Лалевић 2004: M. S. Lalević, Sinonimi i srodne reči srpskohrvatskoga jezika, Beograd: Nolit.

Матешић 1982: J. Matešić, Frazeološki rječnik hrvatskoga ili srpskog jezika, Zagreb: Školska knjiga.

Пипер и др. 2005: П. Пипер, Р. Драгићевић, М. Стефановић, Асоиијативни речник српскога језика, Београд: Београдска књига - Службени лист СЦГ - Филолошки факултет у Београду.

Попова/Стерњин 2007: 3. Д. Попова, И. А. Стернин, Когнитивная лингвистика, Москва: Восток-Запад.

Стефановић 2012: М. Стефановић, Језичка слика породице у руском и српском језику, Нови Сад: Филозофски факултет.

Gordana R. Štrbac

THE ROLE OF DICTIONARIES IN COGNITIVE LINGUISTICS RESEARCH OF SERBIAN

\section{Summary}

The paper discusses the concept of wisdom in order to demonstrate the role of dictionaries in research in the field of cognitive linguistics. The obtained results show that different types of dictionaries have different functions in the process of structuring the concept. In Serbian linguistics, besides general dictionaries, there are also dictionaries of synonyms, derivative dictionaries, phraseological dictionaries and dictionaries of associations. Based on the data provided by these dictionaries, general conclusions can be drawn as to how the speakers of the Serbian language understand the notion of wisdom. Key words: cognitive linguistics, concept wisdom, dictionaries. 